\title{
Evaluating the effect of Cannabis sativa seed extraction on memory
}

\author{
Alireza Moghaddas Yazdi ${ }^{*}$, Morteza Kafaee Razavi ${ }^{1}$ \\ From $1^{\text {st }}$ International Congress on Neurobiology and Clinical Psychopharmacology \\ and European Psychiatric Association Conference on Treatment Guidance \\ Thessaloniki, Greece. 19-22 November 2009
}

\section{Background}

$\triangle 9$-THC is a psychotropic component of Cannabis sativa plant, studies show this matter can bind Cannabinoid receptor in CA1 area of Hippocamp. Thus the aim of this study is evaluation of the effect of aqua extraction Cannabis sativa seed on spatial memory consolidation in rats.

\section{Materials and methods}

Cannabis sativa seed was extracted with Soxhlet apparatus. To test spatial memory, Morris water mazemaze (7 days, 4 trails) was used.

Experimental groups with $25 \mathrm{mg} \cdot \mathrm{kg}^{-1}, 50 \mathrm{mg} \cdot \mathrm{kg}^{-1}$, $150 \mathrm{mg} \cdot \mathrm{kg}^{-1}$ were injected in the peritoneal (IP) and after one hour of injection spatial memory was scaled.

\section{Results}

The results show that experimental groups $\left(50 \mathrm{mg} \cdot \mathrm{kg}^{-1}\right.$, $100 \mathrm{mg} \cdot \mathrm{kg}^{-1}, 150 \mathrm{mg} \cdot \mathrm{kg}^{-1}$ doses), for learning time have significant level deduction in the comparison with control group $(\mathrm{p}<0.05)$.

\section{Conclusions}

We demonstrate Cannabis sativa seed in low doses can cause Spatial memory improvement but in high dose has not significant level in comparison with control group.

\section{Acknowledgements}

We thank Azad University for support.

\section{Author details}

${ }^{1}$ Department of Biology, Azad University of Mashad, Mashhad, Iran

${ }^{2}$ Department of Statitics, Azad University of Mashad, Mashhad, Iran.

Published: 22 April 2010

${ }^{2}$ Department of Statitics, Azad University of Mashad, Mashhad, Iran

\section{References}

1. Ramirez GBelen, Blazquez Cristina, del Pulgar GomezTeresa, Guzman Manuel, de Ceballos LMaria: Prevention of Alzheimer's disease pathology by Cannabinoid:Neuroprtection mediated by blockade of Microglial activation. $j$ neuroscience 2005, 25(8):1904-1913.

2. Le Foll Bernard, Goldberg RSteven: Cannabinoid CB1 receptor antagonist as Promising new Medication for drug Depence. $j$ pharmacology 2004, 312:875-883.

3. Castellano C, Rossi-Arnaud C, Cestari V, Costanzi M: Cannabinoids and memory Animal studies. bentham Science Publishers 2003, 389-402.

4. Hill MN, Gorzalka BB: Impairment in Endocannabinoid signaling and depressive illness. jama 2009, 301(11):1165-11676.

doi:10.1186/1744-859X-9-S1-S208

Cite this article as: Yazdi and Razavi: Evaluating the effect of Cannabis sativa seed extraction on memory. Annals of General Psychiatry 2010 9(Suppl 1):S208.
Submit your next manuscript to BioMed Central and take full advantage of:

- Convenient online submission

- Thorough peer review

- No space constraints or color figure charges

- Immediate publication on acceptance

- Inclusion in PubMed, CAS, Scopus and Google Scholar

- Research which is freely available for redistribution
C Biomed Central 